\title{
Emerging geographies of English localism: the case of neighbourhood planning
}

\section{Introduction}

Since the early years of the twenty-first century, arguments for localism have taken hold across the political spectrum in England influencing the activities of the New Labour Governments (1997-2010) and becoming more prominent during the subsequent Coalition (2010-2015) and Conservative (2015-) governments (and for exemplars of the range of political argument see Clark and Maher, 2003; Corry and Stoker, 2002; The Smith Institute, 2014). Broadly speaking, this agenda involves a shift in policy making and practice to decentralise political power towards local institutions and local people. This paper outlines this emerging localist policy agenda and highlights the salience of the geography of civic infrastructure and capacity in relation to policy outcomes. The paper makes a particular contribution to debate in this field by exploring the development of neighbourhood planning. It draws on original research in three different urban areas of England in order to explore the evolution of neighbourhood planning and its wider implications for the geography of localism.

\section{What is localism?}

In its current policy manifestations localism relates to the devolution of political power from Whitehall and Westminster (the 'centre') to England's localities. These imagined localities potentially include a wide range of 'local' bodies including representatives from city-regions, local authorities, Local Economic Partnerships and other state-funded bodies, as well as communities. In addition, however, the term is also used to capture the ways in which people can be more fully engaged in the political process and civic life through their connections to place. In this second reading of localism, the geographic locale provides the ground on which citizens are called to new forms of agency in relating to each other as well as state-funded bodies and local politicians. In theory at least, these two strands of localism are designed to work together to ensure subsidiarity whereby 'power [is] held at the lowest possible level, whether this is individuals, communities, neighbourhoods, local institutions or local government' (Department for Communities and Local Government, cited in The House of Commons' Select Committee on Communities and Local Government, 2011, 10).

As such, localism is about 'top down' reforms whereby responsibilities, funding and authority are to be taken from parts of government in Whitehall and passed to other bodies such as local authorities. Indeed, many proponents of localism argue that local authorities or combined authorities and/or Local Economic Partnerships should take on a greater role in areas such as infrastructure planning and spending, skills training and public health (Heseltine, 2012; RSA, 2014; O'Brien and Pike, 2015). 
By devolving decision making to those closer to the ground, it is argued that more appropriate and more efficacious decisions will be made with greater accountability for what is done. In addition, many proponents of localism advocate greater financial freedom such that local bodies can decide how to raise and spend the money they have, without interference and control from the centre. With greater financial freedom and a larger brief, localism is about granting civic leaders the space and power to act in the interests of their local communities, thereby trying to generate the economic growth, jobs and well-being that serves both local and national interests. In so doing, it is argued that increased political engagement will follow as local citizens and interested parties have the scope to demand change and hold local politicians accountable for the things that are done. In addition, however, arguments about localism also signal a demand for more 'bottom up' forms of civic engagement. Rather than being about devolving power to more localised arms of the state, this part of the localism agenda is about tapping the capacity of citizens to engage in solving their own problems by working together, sometimes in relationship with the local state and state-funded bodies, but also on their own terms. This kind of localism is really an argument about the place of the people in democratic life. Those subscribing to this form of localism are concerned to unpack the ways in which sharing space in particular places can provide both the social relationships and the common experiences from which citizens can then engage with each other as well as the state, finding solutions to shared sets of concerns (Bryson and Crosby, 1992; Stone et al, 2001; Leighninger, 2006; Saegert, 2006; de Sousa Briggs, 2008).

This second strand of localism has a very long pedigree in democratic thought and practice, as well as government policy. Governments have called for more active citizenship and community self-help since the 1960s. David Cameron's calls for the creation of the 'Big Society' is merely the latest instalment in a long catalogue of government efforts to get citizens to do more (Loney, 1983; Hurd, 1989; Wilson, 1999). The previous Labour governments encouraged Local Authorities to experiment with a range of new tools to engage residents and service users including citizens' juries, focus groups, neighbourhood committees and referenda (Pacione, 1988; Wilson, 1999; Lowndes et al, 2001; Barnes et al, 2003; Barnes et al, 2007; Copus, 2010; Copus and Sweeting, 2012). The idea was to encourage local authorities to provide new experiences to citizens and to foster a 'habit of citizenship' (Pratchett and Wilson, 1996, 241). Today, organisations such as local authorities, hospitals, housing associations and police authorities are being further challenged to cede some authority and power to those living in the local community and/or those using their services (Local Government Task Force, 2014). If this kind of localism develops, it has the potential to develop new relationships between citizens and the state with opportunities for co-commissioning, co-design and co-production (Boyle and Harris, 2010; Cooke and Muir, 2012). 


\section{Making sense of localism}

As suggested above, localism comprises a shift in geographical imaginations about government. Driven more from above than below, localism represents a challenge to the model of government and politics that developed during the twentieth century and in theory at least, it marks a new phase of statecraft. This model is about a central government that devolves political power, authority and responsibility to lower level institutions and people. The vision is that localism will facilitate greater initiative and creativity in public policy making as place-based publics are convened to solve local problems. In this model, the central state is there to facilitate rather than direct what happens on the ground. Localism is about a spatial and institutional pluralisation of government and agency, moving the locus of political power and decision making from a concentrated executive in the capital city towards a wider diversity of actors across the nation-at-large. As a reaction to the perceived centralism of the twentieth century, localism reflects a very different geographical imaginary of governmental power and practice - as broadly characterised in Table 1.

Table 1: The shifting geography of statecraft from centralism towards localism

\begin{tabular}{|l|l|l|}
\hline & Centralism & Localism \\
\hline The vision & $\begin{array}{l}\text { National standards and uniform } \\
\text { delivery }\end{array}$ & Subsidiarity \\
\hline The means & $\begin{array}{l}\text { A national strategy, targets, audit } \\
\text { and local compliance }\end{array}$ & $\begin{array}{l}\text { Local democracy (politicians, voters, lay } \\
\text { representatives and community) }\end{array}$ \\
\hline The fears & The postcode lottery & The lack of local capacity \\
\hline The risks & $\begin{array}{l}\text { Being out-of-touch and unable to } \\
\text { meet the challenges faced; a } \\
\text { democratic deficit }\end{array}$ & $\begin{array}{l}\text { Providing an uneven and uncertain landscape } \\
\text { for business and life; that the loudest voices } \\
\text { determine what's done }\end{array}$ \\
\hline The goals & $\begin{array}{l}\text { Social and spatial equity in access, } \\
\text { experience and outcomes of services }\end{array}$ & $\begin{array}{l}\text { Locally determined and accountable activity } \\
\text { and outcomes }\end{array}$ \\
\hline
\end{tabular}

In the academy localism has been widely understood as a manifestation of the wider shift towards forms of neo-liberal government and governmentality. Rather than attempting to foster spatially uniform economic activity through the use of regional policy, economic development assistance and state-led interventions, neo-liberalising governments have strengthened the market as a way to deliver economic growth despite the spatially uneven effects (Martin et al, 2015; Pike et al, 2014). The widening gap between the North and South of the British economy and the uneven fortunes of different parts of the country are the outcomes of market forces and as such, localism can provide a useful political justification for the resulting spatial inequality and social injustice. In this vein, localism can be understood as the necessary outcome of a beggar-thy-neighbour competition for 
investment and talent between people and their places that has been promoted by the neo-liberal state (Lovering, 1990; Peck and Tickell, 1994, 2012). As Clarke and Cochrane (2013) suggest, localism is a form of spatial (neo)liberalism where by localities are 'freed up' to act in their interests, albeit that local decisions are expected to chime with the requirements of responsible government laid down by the centre, and the outcomes are argued to reflect the ability of local people to solve their own problems.

As such, localist policy is also argued to be part of a wider armoury of neo-liberal discourse that seeks to promote greater personal - and spatial - responsibility for economic success. In the large body of literature about governmentality, scholars have argued that neo-liberal policy discourses have promoted the language of self-help so that people and places are encouraged to solve their own problems and fill the service gaps that are left by a state in retreat (Rose, 1999). As Bacqué and Biewener $(2013,2209)$ point out, this can involve a cynical adoption of the language of radical social movements (about empowerment, self-organisation and local democracy) in order to endorse a conservative agenda whereby 'poor populations are expected to take responsibility for and to selfmanage the issues they face, rather than fostering a democratization of power and leaving aside any questions concerning the redistribution of wealth or social solidarity'. Such discourse has helped to enrol civil society organisations in the doings of the state, reducing their scope to resist (McQuarrie, 2012; Newman and Lake, 2006). Furthermore, in the face of major cuts in Government spending, poor communities are forced to become more self-reliant whether they want to or not. At a time of dramatic cuts in government spending on public services, particularly to local authorities, localism can be argued to provide ideological cover for a national government that needs to enrol new actors in the delivery of services, some of them working for free (Bulley and Sokhi-Bulley, 2014; Davoudi and Madanipour, 2013).

In a recent intervention about the geography of localism, Featherstone and colleagues $(2012,178)$ captured this argument by suggesting that 'localism is being employed to instigate a new round of 'roll-back' neoliberalism involving the dismantling of 'alien institutions' and attacks on public bureaucracies and collective entitlements through the now familiar repertoire of funding cuts, organizational downsizing, market testing and privatisation'. In the context of ongoing neoliberalisation, there is an argument that localism represents the latest attempt by government to wash its hands of responsibility for questions of spatial (in)justice, leaving decisions to local people in a way that further de-politicises the decisions being made. Clarke and Cochrane (2013) use the term 'anti-politics' to describe this process whereby local outcomes are naturalised in relation to market outcomes and participative democracy such that the people get what they are prepared to deliver themselves. As such, they argue that localist discourse and policy works to obscure the politics 
shaping material and spatial outcomes and to obfuscate the potential routes to political contestation. However, they also acknowledge the instability of this situation on the ground. Over time, they suggest, practitioners will find themselves 'confronted by a given political reality of diverse interest groups, complex moral terrains, and needs for collective decisions both within and between localities. We can expect this anti-political strategy to have its moment, but not to become an enduring condition' (Clarke and Cochrane, 2013, 17). Indeed, as Williams and his co-authors (2014) have recently highlighted, the new landscape of localism provides new political opportunities that are yet to be considered in academic debate (and for a similar argument in relation to community-based projects more generally, see Larner, 2015).

In this regard, the ability of local people to take up the opportunities of localism will depend, in part, on their prior organisation and capacity to act. While localism seeks to free up local actors (Clarke and Cochrane's (2013) argument about spatial liberalism), it also depends upon prior and new organisation and capacity, and as such, it casts something of a communitarian light on the nation-atlarge. In this regard, localism is better characterised as a form of liberal institutionalism that reflects a desire to free-up local communities to act in their interests, but that also highlights the importance of having the institutional inheritance and/or civic capacity to respond on the ground.

This kind of liberal institutionalism exposes important - and unresolvable - tensions at the heart of contemporary liberal democracy and its associated culture(s). Classical liberalism is about freeing citizens from the social obligations, customs, traditions, religions and experiences that underpinned political virtue in earlier times, yet as 'practical liberalism' still demands the exercise of such political virtues in order to function, the state then relies on other institutions to produce these effects (Allen, 2006; Mansbridge, 1995; Oldfield, 1990). While social liberals, civic republicans and communitarians have been preoccupied with exactly this issue - trying to foster the institutions that can create political virtue in liberal and secular times (Barber, 1982; Dewey, 2000; Putnam, 2000; Sandel, 1998) - this has often run counter to the dominant liberal trends in society whereby institutional affiliation and rates of popular civic engagement continue to fall (Whiteley, 2012).

The lens of liberal institutionalism highlights the way in which localism will necessarily reflect the ongoing tension between liberalism and civic republicanism or communitarianism. Localism is an ideological and political effort to 'free up' local actors who in turn, will act where they have the institutions (old and new) to do so. As such, it is likely that localism will take deepest root where there is sufficient local interest and capacity to engage. This, in turn, will be more likely in some areas than others, reflecting the nature and composition of local communities, their existing organisation and activity, the presence of civic leaders and key local institutions, as well the 
opportunities that are presented for making a difference. Indeed, the emerging outcomes of localism are already highlighting the uneven distribution of existing civic infrastructure at parish and/or community scales (NALC, 2015; Wills, 2016).

Similar findings have emerged from research conducted into previous efforts to foster greater civic engagement that were developed by local authorities during the New Labour regimes. When Vivian Lowndes and her co-authors (2006) compared the work of eight local authorities across a range of areas and populations they found that it was easier for relationships to develop where the community and voluntary sector had a strong coordinating infrastructure that allowed them to speak with one voice, so increasing their potential power in interactions with public and private organisations. Differences in the organisation of civil society as well as the prevailing political leadership and culture helped to create space for more or less of a relationship between the state and local citizens (and for a more general argument about the importance of institutions in relation to political culture and practice, see also Lowndes, 2009).

The ability to tap a 'devolution dividend' from localist policy in relation to regional economic performance has similarly depended upon local institutions and their capacity to act for regional growth (Raco, 2003; Farole et al, 2011; Tomaney, 2014). Scholars have argued that the prevailing political institutions in any area shape local power relations, mediating economic processes and playing a critical role in shaping incentives for action that in turn, set the trajectory of local culture and practice (Martin, 2010). Going forward, it is important to better understand this map of local institutions and their impact on civic capacity and the prospects for localism, as is outlined further below.

\section{The geography of civic infrastructure and capacity}

In his research into existing patterns of civic engagement in England, Mohan (2011) uses the idea of a 'civic core' to map citizen engagement in civic and charitable activities and not unexpectedly, he finds a highly uneven distribution in the contributions being made. The most active citizens were more likely to be older, wealthier, better educated, longer-term residents with religious beliefs (Mohan, 2011, 9). Those with higher levels of income and greater security, and those with experience of membership in civil society organisations, were more likely to have the skills and interest needed to readily engage in civic and political life. Not surprisingly, such people are unevenly distributed across the country with a greater proportion of them living in wealthier parts of the country (see Figure 1). 
INSERT Figure 1: The distribution of the civic core in relation to the deprivation of home location

In their analysis of the distribution of local organisations and the focus of their work, Mohan and colleagues (see Clifford, 2012) similarly found an inverse relationship between the number of organisations, their financial independence from the state and the socio-economic status of the area. As illustrated in Figure 2, there were fewer organisations focusing on local activities in poorer areas than richer ones, and the organisations in the poorer areas were more dependent upon public funds for their work. Moreover, the civil society organisations that used to provide an important link between poorer communities and political decision-making in England - the trade unions, political parties and religious organisations - have all declined very substantially in recent years (Parry et al, 1992; Whiteley, 2012; Wills, 2012).

INSERT: Figure 2: The number of community and voluntary sector organisations working the neighbourhood scale, by the socio-economic deprivation of the area and funding sources

There are well-known implications of this uneven pattern in community-oriented organisation and related civic capacity. In their research into the dynamics of urban communities in the city of Chicago, USA, for example, Sampson and colleagues found that the organisation of local activity, often of a non-political nature (such as community festivals and recreational activity) created important 'neighbourhood effects' that reflected the density of local organisations and influenced the development of feelings of 'collective efficacy' or shared social expectations about behaviour, social control, trust and cohesion. Indeed, Sampson's data to map the density of local organisations and the incidence of collective civic activity highlights a clear, and path dependent, relationship between organisations and action. His research demonstrates that geography shapes the opportunity for civic engagement because the number and activity of local organisations varies significantly between areas, and this, Sampson suggests, is more important than individual level characteristics (such as ethnicity, class, gender or age) in determining civic activity rates.

Of course, the geography of community and civil society infrastructure - and their related neighbourhood effects - is bound to be uneven across any country and within any jurisdiction. The uneven distribution and quality of local organisations means that the existing - and latent - civic capacity of neighbourhoods will vary greatly from one place to another. In England today, existing data suggests that there is less community organisation in poorer areas, and what there is depends more heavily on the state. Although policy may stimulate the formation of new institutions (as in 
relation to the neighbourhood forums used for neighbourhood planning as outlined further below), localist outcomes are likely to reflect this prevailing geography of civic infrastructure and capacity, and going forward, greater policy attention will need to be focused on the wider consequences of this prevailing uneven geography of civic organisation in England (see also Ware, 2012).

\section{Neighbourhood planning: Research and findings}

Neighbourhood planning has been one of the major new developments in localist policy in England since 2010. New provisions included in the Localism Act (2011) granted new rights to neighbourhood planning and many hundreds of new neighbourhood forums have been set up in urban areas while parish councils have been able to lead on this agenda where they already exist. Historically, planning has had a hierarchical model of authority with the power concentrated at the top of the chain and while not fully overturning this spatial arrangement, the new rights to neighbourhood planning have granted new powers to those local citizens who are able and willing to develop a plan (Gallent and Robinson, 2013). Even though neighbourhood plans have to be in keeping with 'higher level' plans that are already agreed, community-led planning now has statutory status. ${ }^{i}$ Once passed by the Planning Inspector and a referendum of local residents, a neighbourhood plan becomes part of the official planning framework that shapes decisions about development in the area. Given its importance in the localism agenda, and the scale of the take up, neighbourhood planning provides a useful window onto the debates about localism outlined above.

Introduction to the research and the case study forums

I conducted research into neighbourhood planning at a relatively early stage in developments in this field. I selected three cases by looking at the national picture and finding those that were fairly well advanced in a range of different locations ensuring that I captured places with different degrees of prior civic organisation and potential for further development, albeit that all of them required the establishment of a new forum from scratch. Exeter St James was selected because it was the first urban forum to get its plan accepted and as such, it allowed the fullest exploration of the impact of neighbourhood planning in the time allocated for this research. Highgate was chosen as an area with strong civic traditions in London where many argued that neighbourhood planning would be slow to take off. In contrast, the Holbeck forum in Leeds represented a poorer community in a northern urban location where the city council was taking the lead (see Figure 3 and Table 2).

INSERT Figure 3: Map of the case study neighbourhood forums 
Table 2: Background to the case study neighbourhood forums

\begin{tabular}{|l|l|l|l|}
\hline Area - and 'character' & $\begin{array}{l}\text { Population total } \\
\text { (hhs) }\end{array}$ & Key dates & Key issues \\
\hline $\begin{array}{l}\text { Exeter, St James } \\
\text { Inner city, largely } \\
\text { residential, next to the } \\
\text { university. }\end{array}$ & $\begin{array}{l}6,891(2,366) \\
\text { (53\% full time } \\
\text { students up } \\
11 \% \text { from 2001) }\end{array}$ & $\begin{array}{l}\text { Started May 2011 (with } \\
\text { frontrunner funding); } \\
\text { Designation 2012; } \\
\text { Referendum May 2013 } \\
\text { (92\% support) }\end{array}$ & $\begin{array}{l}\text { Sustaining a balanced } \\
\text { community (restricting HMOs); } \\
\text { supporting the residential } \\
\text { community; local economic } \\
\text { development; fostering } \\
\text { community projects. }\end{array}$ \\
\hline $\begin{array}{l}\text { Highgate, London } \\
\text { Suburban village, large } \\
\text { green areas, largely } \\
\text { owner occupied, } \\
\text { expensive property. }\end{array}$ & $\begin{array}{l}18,000(8,100) ; \\
\text { and } 1 / 3 \text { over } 60 \\
\text { yrs. old; 30\% } \\
\text { born abroad }\end{array}$ & $\begin{array}{l}\text { Started January 2012; } \\
\text { Designation 2012; } \\
\text { Draft plan 2015. }\end{array}$ & $\begin{array}{l}\text { Linking two LA areas (Camden } \\
\text { and Haringey); representation } \\
\text { to official bodies (transport, } \\
\text { water); fostering community } \\
\text { projects. }\end{array}$ \\
\hline $\begin{array}{l}\text { Holbeck, Leeds } \\
\text { Inner city, old industrial, } \\
\text { brownfield, transient } \\
\text { rental market, some } \\
\text { longer term residents } \\
\text { and business. }\end{array}$ & $\begin{array}{l}3000 \text { (n/a) } \\
\text { and }\end{array}$ & $\begin{array}{l}\text { Started June 2012 (with } \\
\text { frontrunner funding); } \\
\text { Designation March 2014; } \\
\text { Draft plan 2015. }\end{array}$ & $\begin{array}{l}\text { Initiated with help from the city } \\
\text { council, to attract investment } \\
\text { and development. }\end{array}$ \\
\hline
\end{tabular}

Given that there are now hundreds of urban forums, this research is but a small drop in the larger ocean of emergent neighbourhood planning, and it cannot be understood as fully representative in any rigorous way. However, the research findings from Exeter, London and Leeds are not out of line with the key findings from other research in the field (see especially Parker et al, 2014). Moreover, the work presented here raises a number of issues for further - larger scale - research including the challenges of facilitating civic capacity where it is relatively weak, the extent to which particular forms of leadership are needed to build alliances across civil society groups in order to develop a plan, and the need to sustain the organisation and related activity over years rather than months. As such, this paper can be read as a window onto developments early on in the process of neighbourhood planning and I present the material as a vehicle for thinking about the wider implications of localism for statecraft and citizenship in England today (and to this end, the work is part of a larger project that included research into other interventions such as Neighbourhood Community Budgets, the development of co-operative councils and community organising (see also Wills, 2016)).

Research in the three case study areas - Exeter, Leeds and London - was conducted between February 2014 and Easter 2015. This involved conducting interviews with 15 of the leading protagonists, their partners in the local authorities and local political commentators, as well as attendance at meetings (including public events, planning meetings and AGMs). Key meetings included the 2014 and 2015 AGMs in Highgate, a team meeting in Leeds (in January 2015) and an 
event on neighbourhood planning organised by Leeds City Council at which the Minister for Planning, Nick Boles MP spoke in July 2014. Interviews were recorded and transcribed before analysis, and the quotes used here have been checked with those who are named.

Exeter St James and Highgate are both desirable residential communities although the former has been strongly affected by increased levels of student accommodation that have reduced the stock of family housing available and reconfigured the demographics of the area, providing one of the key motivations for getting a forum established. In contrast, Holbeck is a much less prosperous community. Situated on the edge of the city centre, it has a proud history of being at the centre of Yorkshire's industrial revolution but has been blighted by de-industrialisation, motorway development around the edge of the area and years of neglect. The area comprises an area of backto-back housing where an estimated 1 in 6 of the properties are empty, several social housing estates and a significant number of industrial units. Many respondents described the area as being 'low rent' and as having 'a transient population.' In contrast to Exeter and Highgate where the communities were already firmed established and relatively well-organised to act for themselves, the civic ground from which to develop neighbourhood planning was far less fertile in Holbeck.

The forum in Exeter St James was one of the first set up in the country (in May 2011) and they worked fast to develop their plan securing a successful referendum result in May 2013. The plan includes ideas to develop a better hub for the community, a number of identified sites for development, improved access to the area, protection for green spaces and better traffic management as well as five community projects that were to provide a focus for the forum once the plan was adopted. The plan was designed 'to ensure that St James is a vibrant neighbourhood with a balanced and diverse community. It will be a great place to live and work close to the city centre and University and will support Exeter's character, identity and cultural life. St James will become known by people at all stages of their live as one of the best parts of the city in which to live' (Exeter St James Forum, 2013, 13).

In Highgate, North London, the forum was founded a year later than the one in Exeter (in early 2012) but they had to change national legislation in order to get permission to straddle the geographical boundaries of two local authorities. Indeed, part of the motivation for the Highgate plan was to overcome the legacy of being split down the middle by a local authority boundary such that: 'Highgate is an area, in planning terms, which is split between a number of London boroughs and has never benefitted from a cohesive and singular set of development guidelines that recognise and seek to preserve the unique character and needs of the neighbourhood area' (Highgate Neighbourhood Forum, 2015, 6). The ambitious draft plan published in early 2015 stretched to 100 
pages and declared its ambition that: 'Highgate should grow and prosper as a united community across the artificial boundary between the London Boroughs of Camden and Haringey. It should be a vibrant place that protects its unique character and heritage, while embracing new ideas and beneficial change. It should be home to a community that can work together to meet local needs, while respecting its differences and diversity. It should be a neighbourhood that complements and connects with neighbouring communities. All of these factors combined should make Highgate a better place to both live and work' (Highgate Neighbourhood Forum, 2015, 19). The plan then introduced five core objectives (covering social and community needs, economic activity, traffic and transport, open spaces and public realm, development and heritage) with 17 more specific subobjectives that formed the basis of the proposed new planning policy for Highgate for the next 15 years (2015-2013). As in Exeter, the plan also included an action plan for the community, identifying as many as 36 different areas for action that could improve the area beyond the process of planning.

At the end of three years of work the Holbeck neighbourhood forum did not yet have a published draft plan but they had published a vision to make Holbeck 'a more attractive and healthier place for everyone, it will have a thriving local centre with a range of community facilities, a choice of quality but affordable housing, a variety of local job opportunities, all set in a green environment, respecting the heritage of the area, and well connected to the city centre and adjoining neighbourhoods' ${ }^{. i}$ The forum were holding regular meetings and consulting people around the themes of housing, environment, traffic and transport, heritage, economy and employment, community facilities and services. In line with the other forums, they had secured some funding from national government schemes to hire professional help in drafting their plan. As in Highgate, the team in Holbeck had started work in 2012, but it had taken almost two years to secure designation and the process of drafting the plan was a much slower affair.

In what follows I look at the way in which neighbourhood planning reflected the existing civic infrastructure and capacity in each location, the way in which it has, however, further galvanised and strengthened local community organisation, and the extent to which it has allowed local groups to reconfigure their relationships with government bodies.

\section{Galvanising community capacity}

In all three of the study areas, the leading activists involved in developing the neighbourhood forums were already involved in local community organisations and/or activity prior to setting up a forum and creating a plan. In Exeter, for example, the first chair of the forum, Jo Hawkins, had a career as a 
community relations advisor to developers before she turned her hand to galvanising the team in Exeter St James. Similarly, in Highgate, the first chair of the forum, Maggy Meade-King, had prior experience in community activity as a school governor and relevant skills through her previous employment lobbying government. The second chair, Rachel Allison, who took over in 2014, had previously been a councillor in Haringey, and she brought a wealth of political experience into the work of the forum. In Leeds, too, the first chair, Dennis Kitchen, was active in his residents association, he was a governor at the local primary school, he was leading a team of volunteers who were keeping the local working men's club open, he belonged to Holbeck in Bloom and he was active in a local Christian fellowship group.

Thus the forums were chaired by local people who already knew how to take the initiative to make things happen, and they were capable of galvanising other people to act. In addition, however, particularly in Exeter and Highgate, the forums were able to draw upon a number of existing organisations and local social networks to foster support for the idea of a neighbourhood plan. In 2011, Maggy Meade-King, took the initiative to explore the idea of setting up neighbourhood planning in Highgate and even before the forum could be established, Maggy and contacts from the Highgate Society had to lobby parliament, to change the law and allow a neighbourhood forum to straddle two boroughs. In so doing, they also had to work with six borough councillors - three from each of the boroughs - and at that time, they were from three different political parties (Labour, Liberal Democrat and Green). Maggy had a meeting with them and won their support at the start of the process and then engaged them in the subsequent work of the plan.ii

By January 2012, Maggy invited all potentially interested parties in the Highgate area, including local community groups and the 6 councillors, to a meeting to start the work of the forum and as many as 80 people turned up. In reflecting on this experience she highlighted the different pockets of organisation in the area contrasting the Highgate Society which has a long history of work to protect the area and its heritage, with an active group supporting the local park, faith groups and schools, and the 20 residents' associations that later got involved, as well as individuals who had never been involved with any local group. The forum brought these people together around a shared interest in developing a neighbourhood plan and was able to build upon the existing social infrastructure of these local networks, sending out newsletters and conducting consultation activities through each organised group, as well as having the new channels set up by the forum.

Similarly, in Exeter, Jo Hawkins and others started to galvanise support by contacting the six residents associations that were already active in the ward and when a community meeting was called in May 2011, as many as 90 people attended. In contrast, however, in Holbeck, the council 
took a more prominent role in the work to establish the forum. While the forum similarly drew on the existing organisational networks of local residents associations and social groups, these were relatively weak in the area of Holbeck itself. Dennis Kitchen, the chair, lived just outside the area as did a number of others involved in the forum. The local groups that were active in the area (Holbeck in Bloom, Holbeck Gala, a group running the soup kitchen, a Christian fellowship and a group called Mosaic Church, and another running the local working men's club) were also often led by people who lived outside the area and in this context, getting the neighbourhood forum established would have been very difficult without additional outside support. As Dennis explained, it all started off 'with an approach from the council ... [and] without their involvement, we wouldn't have got this far.' Ian McKay, the city council's Neighbourhood Planning Officer, chaired the steering group that predated the forum and he facilitated extra support. In addition, the forum was supported by a number of volunteers from Planning Aid England as well as a retired planner who lived in the city and who worked with the group to develop their plan.

The Labour-led city council in Leeds had decided to support neighbourhood planning in a number of areas and while Holbeck was the first, there were fledgling groups in Seacroft, Little Woodhouse, Hyde Park, Headlingly, Kirkstall and Beeston. ${ }^{\text {iv }}$ Ian MacKay argued that the council wanted to balance the designation of forums that already covered the richer suburban and rural parishes on the edge of the city. They also saw the new law as a way to bolster community level organisation and give them a better chance to engage with local people over the issue of planning. In early 2012, lan contacted the three existing residents groups in the area of Holbeck and he then worked with them to submit an application for 'frontrunner' status that provided additional funding from national government to cover the work. He recalled that it 'took a lot of work to do that, people needed convincing' and even once they'd agreed to act, the steering group needed a lot of extra support.

In this regard, lan also chaired the group prior to its formal designation in April 2014. The city council facilitated a number of planning workshops to help focus the ideas being developed in the plan and these were attended by a wide range of council officers from the teams responsible for regeneration, conservation, traffic and transport, health and wellbeing. Whereas in the other areas covered by my research, the forums were meeting on their own, developing their own ideas and then taking the initiative to contact local council officers and a range of stakeholders, in Holbeck, the city council planning team were taking the lead. In many ways, the forum provided a way for statefunded organisations to better coordinate what they were already trying to do. While the community were part of the forum, and they were involved in consultation over the development of ideas for the plan, the city council staff were largely driving the process. 
In this regard, the Leeds example seems to confirm the widespread expectation that neighbourhood planning (and localism more broadly) will only take off where there are sufficient numbers of middle class people and/or existing community organisations to lead on the plan. Indeed, one of the councillors who represented the area was rather dubious about the idea to undertake this work in Holbeck because the area lacked the 'professional people who could have done it on their own'. Moreover, it made extra demands on the small number of people - herself included - who were already doing remarkable amounts of local community work. While the cases of Exeter and Highgate clearly demonstrated the importance of having skilled, professional people who were able to take the lead in the work of the forum, it was clear that the existing social networks in Holbeck were probably too weak to have catalysed a neighbourhood forum without external support. While the city council was helping to support the forum and nurture its work, council staff were trying to fill a vacuum in local civic capacity and it was not clear whether this was going to be sufficient to generate the independent civic organisation that would be needed to realise the ideas being developed as part of the plan.

Developing a vision for the people and place

Each forum spent considerable time consulting local people about their feelings about their area and their ideas for improvements. During the Summer of 2012, the Highgate forum distributed questionnaires to every household in the area backed up with online access to the survey, asking people what they liked and disliked about the area, and what it needs with space for additional comments and a chance to sign up to stay in touch with the forum. The survey generated hundreds of responses and in their own summary, the forum emphasised the extent to which people appreciated the 'village atmosphere', the built environment, local amenities and green spaces. Echoing Sampson's (2012) findings about the importance of community efficacy in Chicago, they also found that people appreciated the fact that it was the kind of place where 'people care about what happens'. The forum identified traffic, parking, transport provision, retailing and the protection of green spaces as areas for improvement and these have been key to the plan. The forum subsequently revisited the community to explore more detailed ideas about these concerns, and following the publication of the draft plan in 2015, a second round of consultation also helped to increase local engagement in the work they were doing.

Of course, such consultation generated conflict, and in Highgate where as many as 50 people were involved in different groups working on the different parts of the plan, tensions sometimes arose. As Maggy remarked, 'it's not all sunshine and light. There are people frustrated that other people won't 
do what they want them to do and don't agree with them about what the policies should be and all that sort of thing.' As a community project, there was no-one in the forum able and willing to exercise the authority that might have helped to speed things along. The planning groups had to work things out and reach a compromise, however long this might take.

In contrast, the team in Holbeck started from a very different position. Their area had been the focus of intensive periods of council-led planning and local consultation in the past and the local residents groups were used to sending representatives to a local Community Association Group (CAG) that worked with the council to oversee local regeneration including the development of a Private Finance Initiative (PFI) to build new housing in the area during the New Labour years. Dennis and Anne Hooper, another member of the forum, had sat on the CAG for Holbeck for as long as seven years and much of their work had been overturned by the subsequent collapse in the market for housing. When they were approached to get involved in the neighbourhood plan, it felt like a continuation of this previous work. They were used to working with the council to try and shape development in the area, and neighbourhood planning was more of the same. Although the forum was supposed to be led by 'the people', there was insufficient independent community selforganisation for this to happen, and the council stepped in to continue its work.

The neighbourhood forum galvanised a small number of community representatives to work with city council officials to consult local people and try to develop a plan. Dennis argued that they wanted to make Holbeck 'a place not just to pass through but to become a destination ... we want to make it into more of an area', but given the scale of the problems they faced, it was essential for state-funded organisations to lead in this work. The forum was keen to explore options for valuing the industrial heritage of the area and seeing the potential to make more of the old buildings and infrastructure that had fallen into decline and disuse. Indeed, the area had developed as an industrial centre in the early nineteenth century when it became famous for its mills, ironworks and machine-making. The man who later became the first mill-owner to sit in parliament, Sir John Marshall, built a six story water-powered flax mill in Holbeck in 1791. Next door, in 1836, he built a larger Egyptian-style mill that stretched over two acres and it still stands today. At its height, this factory grazed cattle on the meadow on top of the roof and yet much of this remarkable industrial heritage is left neglected. An old viaduct built in blue brickwork (and founded in 1879) that runs through the area is unprotected and largely ignored. As a result, the neighbourhood forum were trying to make more of this history in the work of their plan.

Of course, these projects might have been developed by the officers of the city council without the work of the forum, but neighbourhood planning was providing a way for officers to work more 
closely with local people and to plan things together. For lan Mackay, it was also a way to foster relationships between the professionals who were already working in Holbeck. As he put it, the critical relationships are 'not just between the council and the people in Holbeck, it's actually within the council and in many ways, you could argue that's the most critical part of the jigsaw.' Indeed, steering investment and the necessary regeneration activity in an area like Holbeck made planning extremely difficult unless the different professions and their organisations were working together. The existence of the neighbourhood forum and efforts to hold regular planning workshops that included community representatives as well as professional groups made this much easier to do than had been the case in the past.

In other areas, however, it was clear that the forums were developing ideas and activities that would not have been advanced by local government in the absence of the forum. In Exeter, a team of volunteers had focused on improving a green space called Queen's Crescent garden that had been neglected for years. Indeed, Jo Hawkins reported that the area - once called a pleasure garden when it was created in the nineteenth century - had not been maintained since 'at least 1930.' For Jo Hawkins the first chair in Exeter, the forum and plan had galvanised people to improve Queen's Crescent garden by giving them the sanction to act. The neighbourhood plan included a section on the garden (policy EN3) and in early 2014, the forum held some design workshops with local people to develop their ideas for the space. People were keen on getting rid of the walls round the garden, opening up the space, adding a children's playground, some new planting and a hard standing area that could be used for events. As part of this work, the forum also established a Friends of Queens Crescent Garden group that allowed them to 'bring in new blood'. The project had also allowed the forum to forge closer links with the mosque and the primary school adjacent to the site and they were keen to widen the group of people involved.

In October 2014, the forum took this work further by launching a new community benefit society called Exeter St James Trust Ltd that was designed as a vehicle for implementing their plan for the site. Members of the community were invited to buy a minimum of five shares (costing $f 1$ each) and they had sold 2305 shares by the time of the first public meeting held on $16^{\text {th }}$ January 2015 . The four-strong board of directors (all from steering group of the neighbourhood forum) were elected by the 60-strong meeting and they outlined their plans to raise funds to support the development and make the case to the council for planning permission. Once agreed, this would allow the council to then make a compulsory purchase order for the site and lease it to the trust for a minimal fee.

In addition to the work at the garden, the forum were establishing close relationships with a number of important local organisations as part of their activity to support the work of the plan. Early on 
they had forged close relationships with local businesses, and John Lewis - the local department store on the edge of the ward - had sponsored their campaign during the referendum in 2013. They had also established a liaison panel with the university to look 'at the long term issues and the university's ambitions.' They were working closely with senior people from the university but were also including the students' union and the neighbourhood partnership from the neighbouring ward of St David's that also adjoined the university's grounds. A similar initiative was being developed in relation to transport to ensure that the local community had a voice in plans to redevelop the bus garage and reorganise bus routes. The forum were representing local people and their interests with agents of government such as the council, transport bodies and the university.

Similarly, in Highgate, the forum had galvanised a group of people to secure a green area called The Bowl. The Friends of Highgate Bowl was set up in 2014 to protect the site from development with the aim of raising the funds to buy it and then develop it further for community use. This was one of a number of community activities reported at the fourth Annual General Meeting (AGM) of the Highgate neighbourhood forum in May 2015. By working together on the basis of their shared interests in the protection and development of the local area, the forum had identified nine different action groups and this list included: developing opportunities for local volunteering; support for local businesses (including the need to protect premises from increasing rents, and the potential for fostering synergies between them and the local community); advocating for the needs of pedestrians and cyclists with Local Authorities and Transport for London (TfL); ongoing work to improve local bus routes with TfL (including the provision of better east-west connections); looking after small open spaces; activity to support renewable energy; heritage and the public realm. Many of the 80 people present were already engaged in this work and others signed up to take part.

\section{Questions of power in the process of planning}

Respondents from each of the areas argued that neighbourhood planning was reshaping the way things were done in their localities. In all three areas, the key protagonists told me that in the past local residents had often complained about things rather than feeling able to do things themselves. As Di Boston in Exeter reflected: 'I used to hate going to residents association meeting because people would moan all the time about all the things that I was fed up with too. But nobody would do anything'. Similarly, Dennis reported of the residents groups: 'People are very quick, especially in these residents' groups, to come along and moan about what's not been done. This has not been picked up or that's an area that's not been looked after, and they come with all their moans but not 
any constructive things, you know, positive things. It's all looking at the negatives. And [now through the forum] they've got to try and make Holbeck into a positive area to live'.

In each case, the forums welcomed the chance to exercise control over planning and development but in Exeter and Highgate where the process was furthest advanced, and the initiative lay with the community rather than the council, some planning professionals raised a number of concerns about the process of neighbourhood planning. One officer suggested that while neighbourhood planning was positive in stimulating community organisation, he argued that it had given local people a false sense of their own powers in planning. Indeed, once a neighbourhood plan becomes part of the local authority's local development plan, the forum has no continued formal involvement. Thus in Exeter, the council staff felt that the Exeter St James Forum had failed to understand their limited role in the future of planning. As one planning officer put it: 'I think one of the problems with the system is that ... the community probably thought they were going to become the Planning Authority, that they would have a greater discretion in applying the policies. The reality is [that] whilst they produced the policies and obviously, we helped them do that, the reality is it's our judgement as to whether something complies with the policy, and with so many planning policies, they are questions of degree.' This question of judgement was also raised by officers in North London who highlighted the scope for conflict over the interpretation of the policies laid down in the draft Highgate plan.

This issue actually came to a head in Exeter during 2014 when the forum clashed with the council over its interpretation of the plan in regard to a proposed development of an old pavilion on a cricket ground in Exeter St James. The plan was to demolish the pavilion (built in 1904) and put up four multi-storey blocks for 159 students. When this planning application came forward, the forum objected on the ground that it was against a specific policy in the neighbourhood plan, but the council planning committee made their own decision against the views of the forum. The Exeter St James Forum then initiated a judicial review against the council. In this context, the planning authority and the developer then acted to reach a compromise by going back to the applicant who made some amendments to the design that were accepted by both the council and forum. The officer involved reported having 'discussions about how we handle things in future to try and make sure that they [the forum] feel their views are given weight' but it was clear that the forum had tested the balance of power. Indeed, a representative from the Exeter St James Forum welcomed a change in relations after this case reporting that now 'the council agreed that although we were not a statutory consultee ... this could have been handled a lot better and in future, when we meet developers or major applicants, especially if is related to policies ... a case officer ... will come and then have a separate meeting with us to find out what we thought about things so that we don't 
reach the stage where we either have to start or threaten litigation again. It was a compromise but that was an achievement.'

Following this experience the forum had strengthened its planning and design panel so that they were better able to defend the plan be 'more assertive'. It was this body that would liaise with developers as well as the council and they were anticipating change at the local football ground that would further test their mettle in future. In this regard, one planning officer in North London reflected that in the past 'we produce a plan, we consult [and] you tell us what you think of it but this is the opposite. You're doing a plan, you come to us, you show us what you've done and we comment on it and we're helping you, so it reverses that relationship.' While he anticipated conflict over the interpretation of the plan once it was adopted, he also recognised the significance of this shift in the balance of power saying that: 'it is a significant transfer of power ... you have the chance to have a plan that has teeth that is written by you, it is a big thing ... Ultimately, their plan has the same weight as our plan.' As such, the legislation has started to reconfigure the balance of power between organised community groups and local authorities. However modest this is in practice, it represents an opportunity to forge new relationships with the state and ultimately, it has the potential to foster greater local civic capacity across a range of different concerns.

\section{The emerging geography of localism}

As indicated in this study of neighbourhood planning, localist state-craft has opened up political opportunities for a cadre of citizens to engage in the development of their local communities and to reconfigure the balance of power between citizens and the state. Furthermore, neighbourhood planning has stimulated the creation of new civic infrastructure (the neighbourhood forum) that provides an organisational basis from which to act across a wider range of concerns. Given the efforts being made by state-funded bodies to engage with citizens in the delivery of services, there are now opportunities for these emerging neighbourhood forums to take on a wider role in governing their local communities. Indeed, in urban areas, there is the potential for these forums to become new parish or community councils where they can use precept-generated income to service their own organisation, to foster new activities and provide services. A group of community activists in Queen's Park, Westminster, have now successfully done this and they are developing a neighbourhood plan alongside a more ambitious schedule of annual activities (a fireworks night and a summer festival), with support for local groups (via a new grant-giving scheme) and regular communications with residents (via a quarterly newsletter) (Wills, 2016). 
Neighbourhood planning has exposed the way in which the scalar shift of authority in planning however limited - has opened up new political opportunities for local people to engage in decisionmaking, and to build a new institution (the forum) from which they can challenge the local state in its various forms (including local councils, transport authorities, and education providers). As one research respondent from a planning department described it, the community has secured 'legitimacy through the legislation' and as a result, organised communities have a stronger vehicle for civic engagement, voice and action around - but beyond - matters of planning. However, in areas where such civic capacity remains weak, much more preliminary work is needed to foster the social relationships and skills on which it depends. While the local council is trying to do this in Holbeck in Leeds, it has proved very challenging and it is unlikely that anything as ambitious as community-led planning can take off in places where the existing civic capacity remains very weak. As such, neighbourhood planning reflects my characterisation of localism as a form of liberal institutionalism and while it seeks to 'free up' local organisations and people to act, it also depends on the existence of local institutions and existing capacity to facilitate a local response. As such, localist statecraft is likely to widen spatial variations in policy, practice and outcomes across the country as different places are more or less able to respond to the new civic offers being made by the state. In tandem with arguments being made by Williams and his co-authors (2014), the evidence presented in this paper suggests that localism can be understood as providing new opportunities for citizens to change the trajectory of local development and the balance of political power, albeit that this will only be possible in places where local people are able and willing to organise a collective response. Going forward, the development of localism will demand greater attention to the implications of the uneven geography of civic capacity and the need for new ways to foster local organisation.

\section{Acknowledgements}

I am very grateful to the Leverhulme Trust for the fellowship which supported this research as well as all those who took part.

\section{Figure 1:}


The distribution of the 'civic core' in relation to the deprivation of their home location

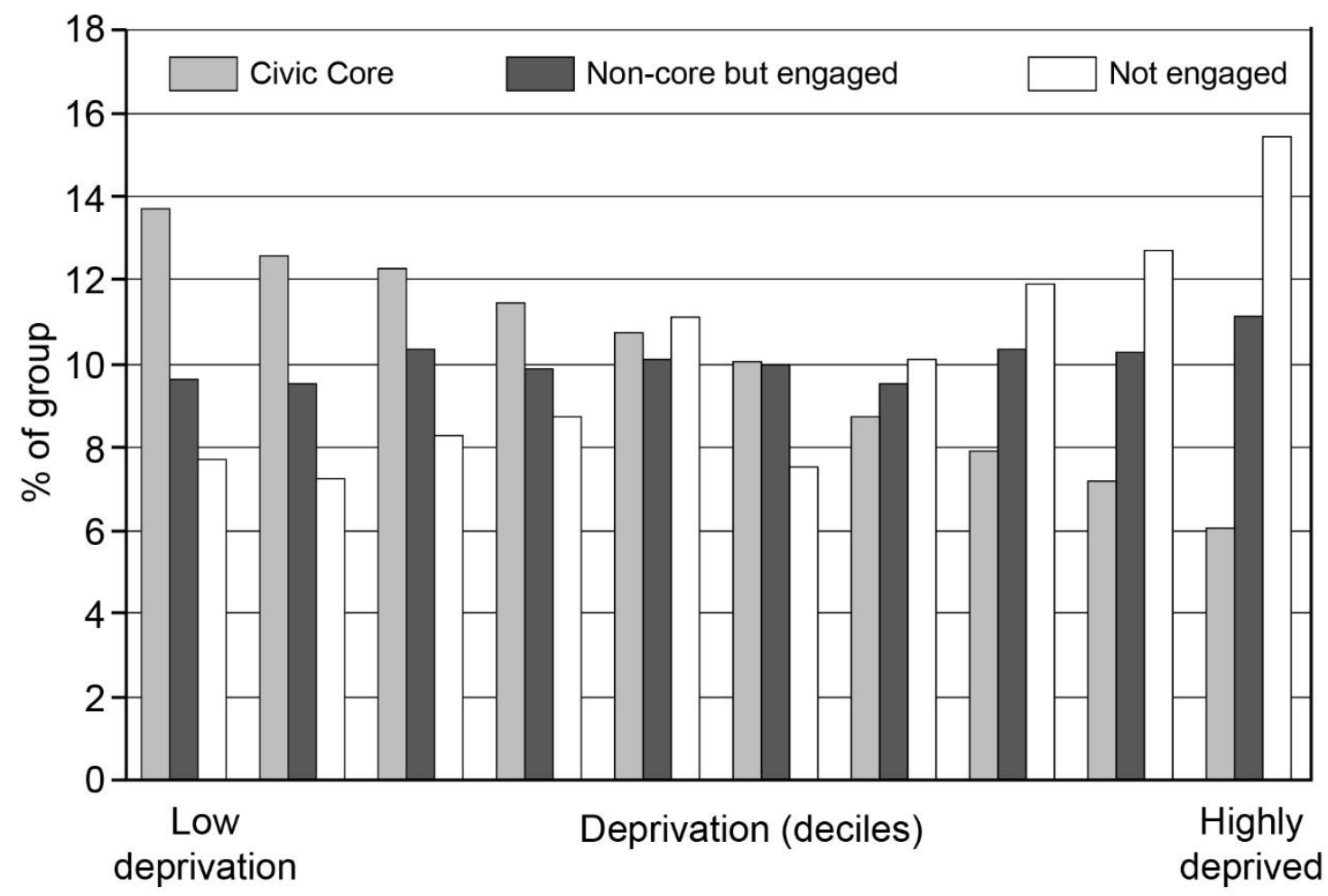

Source: Mohan $(2011,10)$

Note: Deprivation is reported in relation to the Index of Market Deprivation (IMD), by deciles.

Figure 2: 
The prevalence of neighbourhood organisations (standardised by population age) by level of deprivation

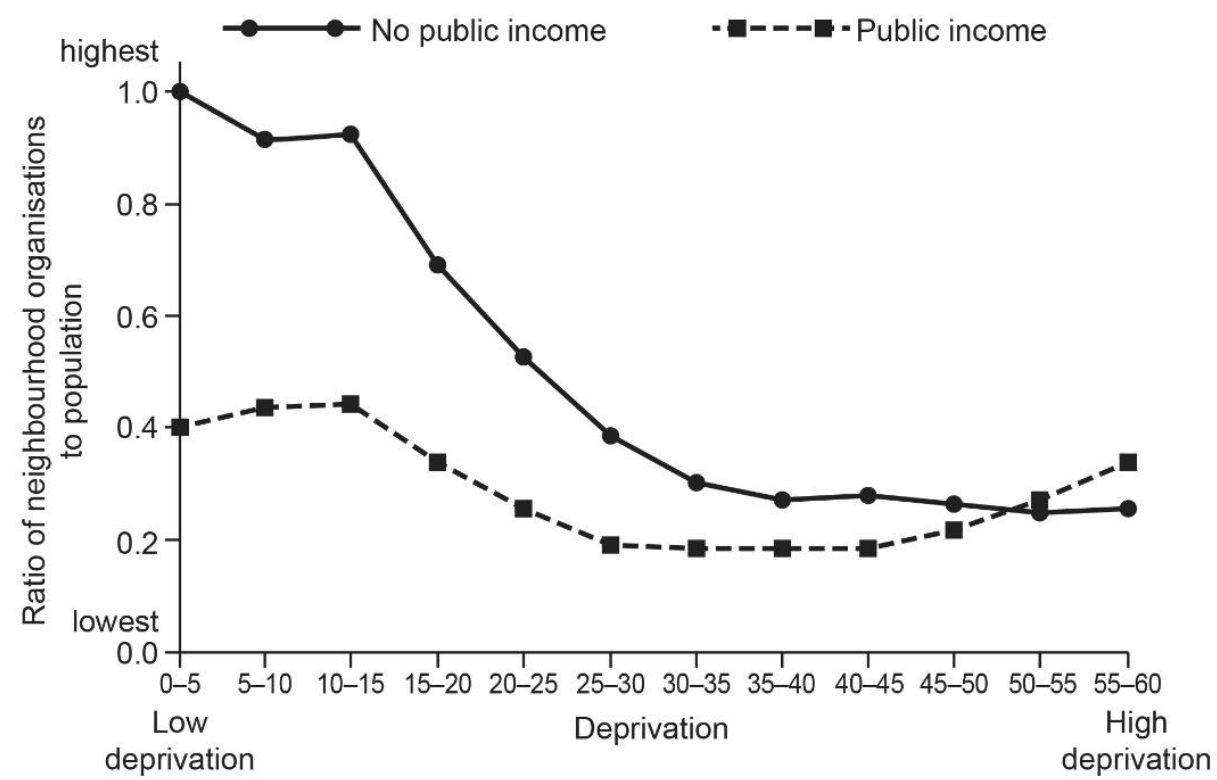

Source: Mohan $(2011,7)$

Note: The vertical axis shows the ratio of charitable organisations operating at the neighbourhood scale in relation to population, standardised to 1 for the highest ratio. This ratio is mapped by area in relation to the Index of Material Deprivation on the horizontal axis.

Figure 3: 


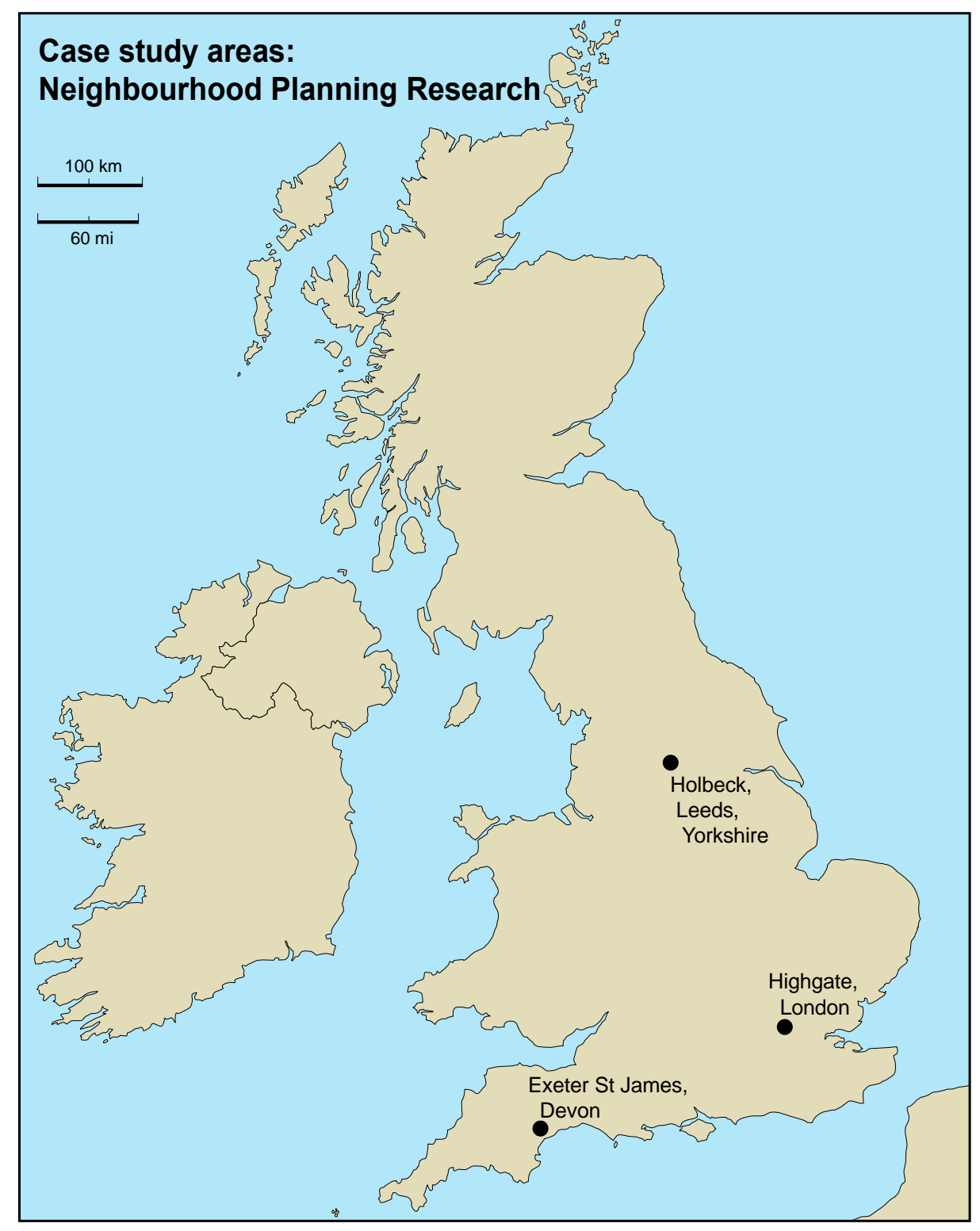

\section{References}

Allen, D. (2006) Talking to strangers: Anxieties of citizenship since Brown V. Board of Education. Chicago: University of Chicago Press.

Bacqué, M-H and Biewener, C. (2013) Different manifestations of the concept of empowerment: The politics of urban renewal in the US and the UK. International Journal of Urban and Regional Research, 37, 6, 2198-2213. 
Barber, B R. (2003) [1984] Strong democracy: Participatory politics for a new age. Oakland: California University Press

Barnes, M. Newman, J. Knops, A. and Sullivan, H. (2003) Constituting 'the public' in public participation. Public Administration, 81, 2, 379-399.

Barnes, M. Newman, J. and Sullivan, H. (2007) Power, participation and political renewal: Case studies in participation. Bristol: Policy Press

Bogdanor, V. (2009) The new British constitution, Oxford: Hart Publishing

Boyle, D. and Harris, M. (2010) The challenge of co-production: How equal partnerships between professionals and the public are crucial to improving services. London: New Economics Foundation

Brownill, S. (1990) Developing London's Docklands - Another Great Planning Disaster? London: Paul Chapman

Bryson, J. M. and Crosby, B. (1992) Leadership for the common good: Tackling public problems in a shared-power world. San Francisco CA: Jossey-Bass

Bulley, D. and Sokhi-Bulley, B. (2014) Big Society as Big Government: Cameron's governmentality agenda. The British Journal of Politics and International Relations, 16, 3, 452-470

Clark, G. and Maher, J. (2003) Total politics: Labour's command state. London: The Conservative Party Unit.

Clarke, N. and Cochrane, A. (2013) Geographies and politics of localism, Political Geography, 34, 1023

Clifford, D. (2012) Voluntary sector organisations working at the neighbourhood level in England: Patterns by local area deprivation. Environment and Planning A, 44, 1148-64.

Colenutt, B. (1991) London Docklands Development Corporation-has the community benefited? in M. Keith and A. Rogers (eds), Hollow Promises: Rhetoric and Reality in the Inner City, London: Mansell, 31-41

Cooke, G. and Muir, R. (2012) (eds) The relational state: How recognising the importance of human relationships could revolutionise the role of the state. London: IPPR

Copus, C. (2010) The councillor: governor, governing and the complexity of citizen engagement, British Journal of Politics and International Relations, 12, 569-589

Copus, C and Sweeting, D. (2012) Whatever happened to local democracy? Policy and Politics, 40, 1, 21-38

Corry, D. and Stoker, G. (2002) New localism: Refashioning the centre-local relation. London: New Local Government Network.

Davoudi, S. and Madanipour, A. (2013) Localism and neo-liberal governmentality, Town Planning Review, 84, 5, 551-562

De Sousa Briggs, X. (2008) Democracy as problem solving: Civic capacity in communities across the globe. Cambridge Mass: MIT

Dewey, J. (2000) [1935] Liberalism and social action. New York: Prometheus Books

Exeter St James Forum (2013) Exeter St James Neighbourhood Plan, available from: http://www.exeterstjamesforum.org/home (last accessed 2.8.15) 
Farole, T. Rodriguez-Pose, A. and Storper, M. (2011) Human Geography and the institutions that underlie economic growth. Progress in Human Geography, 35, 1, 58-80

Featherstone, D. Ince, A. MacKinnon, D. Strauss, K. and Cumbers, A. (2012) Progressive localism and the construction of political alternatives. Transactions of the Institute of British Geographers, 37, 177-182

Gallent, N. and Robinson, S. (2013) Neighbourhood planning: Communities, networks and governance. Bristol: Policy Press

Heseltine, M. (2012) No stone unturned: One man's vision, HM Government, available from: https://www.gov.uk/government/uploads/system/uploads/attachment data/file/34648/12-1213no-stone-unturned-in-pursuit-of-growth.pdf (last accessed 13.07.15)

Highgate Neighbourhood Forum (2015) Draft neighbourhood plan, available from: http://www.highgateneighbourhoodforum.org.uk/ (last accessed 2.8.15)

Hurd, D. (1989) Citizenship in the Tory democracy, New Statesman, $29^{\text {th }}$ April

Larner, W. (2015) The limits of post-politics: Rethinking radical social enterprise, in J. Wilson and E. Swyngedouw (eds) The post-political and its discontents: Spaces of depoliticisation, spectres of radical politics. Edinburgh: Edinburgh University Press, 189-207.

Leighninger, M. (2006) The next form of democracy: How expert rule is giving way to shared governance ... and why politics will never be the same. Nashville: Vanderbilt University Press.

Local Government Taskforce (2014) People-powered public services (commissioned for the Labour Party Policy Review), available from:

http://Igalabour.local.gov.uk/documents/330956/6335671/INNOVATION+TASKFORCE+FINAL+REPO RT.pdf (last accessed on 13.07.15)

Loney, M. (1983) Community against government: The British Community Development Project, 1968-1978 - A study of government incompetence. London: Heinemann

Lovering, J. (1990) Fordism's unknown successor: a comment on Scott's theory of flexible accumulation and the re-emergence of regional economies. International Journal of Urban and Regional Research 14, 159-74.

Lowndes, V. (2009) New institutionalism and urban politics, in J. Davies and D. Imbroscio (eds) Theories of Urban Politics. London: Sage, 91-105.

Lowndes, V. Pratchett, L. and Stoker, G. (2001) Trends in public participation: Part 1 - local government perspectives. Public Administration, 79, 1, 205-222.

Lowndes, V. Pratchett, L. and Stoker, G. (2006) Local political participation: The impact of rules-inuse. Public Administration, 84, 3, 539-561.

Mansbridge, J. (1995) Does participation make better citizens? The Good Society, 5, 2, 1 and 4-7

Martin, R. L. (2010) Rethinking regional path dependence: Beyond lock-in to evolution. Economic Geography, 86, 1, 1-27

Martin R. Pike A. Tyler P. and Gardiner B. (2015) Spatially rebalancing the UK economy: The need for a new policy model. Seaford: Regional Studies Association.

Mohan, J. (2011) Mapping the Big Society, Third Sector Research Centre, Working Paper 62, University of Birmingham, available from:

http://www.birmingham.ac.uk/generic/tsrc/documents/tsrc/working-papers/working-paper-62 pdf 
Newman, K. and Lake, R. W. (2006) Democracy, bureaucracy and difference in US community development politics since 1968. Progress in Human Geography, 31, 1, 44-61

NALC (National Association of Local Councils) (2015) Devo-local: A white paper for empowering and strengthening local democracy. London: NALC.

O'Brien, P. and Pike, A. (2015) City deals, decentralisation and the governance of local infrastructure funding and financing in the UK. NIESR special issue (forthcoming)

Oldfield, A. (1990) Citizenship: An unnatural practice? The Political Quarterly, 61, 2, 177-187

Parker, G. with Lynn, T. Wargent, M. and Locality (2014) User experience of neighbourhood planning in England. London: Locality

Peck, J. and Tickell, A. (1994) Jungle law breaks out: neoliberalism and global-local disorder. Area, 26, 4, 317-26.

Peck, J. and Tickell, A. (2012) Apparitions of neoliberalism: revisiting 'Jungle law breaks out'. Area, 44, 2, 245-49.

Pike A. Rodriguez-Pose A. and Tomaney, J. (2014) Local and regional development in the Global North and South. Progress in Development Studies, 14, 1, 21-30.

Pratchett, L and Wilson, D. (1996) What future for local democracy? in L. Pratchett and D. Wilson (eds) Local democracy and local government, Basingstoke: Macmillan, 229-249.

Putnam, R. (1993) Making democracy work: Civic traditions in modern Italy. Princeton, New Jersey: Princeton University Press

Raco, M. (2003) Governmentality, subject-building, and the discourses and practices of devolution in the UK. Transactions of the Institute of British Geography, 28, 1, 75-95

Rose, N. (1999) Governing the soul: The shaping of the private self [second edition]. London: Free Association Books

Royal Society of Arts (RSA) City Growth Commission (2014) Unleashing metro growth: Final recommendations of the City Growth Commission, available from:

http://www.citygrowthcommission.com/publication/final-report-unleashing-metro-growth/ (last accessed 13.07.15)

Saegert, S. (2006) Building civic capacity in urban neighbourhoods: An empirically grounded anatomy. Journal of Urban Affairs, 28, 3, 275-294

Sampson, R. J. (2012) Great American City: Chicago and the enduring neighbourhood effect. Chicago: Chicago University Press

Sandel, M. (1996) Democracy's discontent: America in search of a public philosophy. Cambridge Mass: Harvard University Press

Stone, C. N. Henig, J R. Jones, B. D. and Pierannunzi, C. (2001) Building civic capacity: The politics of reforming urban schools. Kansas: University of Kansas Press

The Smith Institute (2014)(ed) Labour and localism: Perspectives on an English new deal. London: The Smith Institute.

Tomaney, J. (2014) Region and place I: Institutions. Progress in Human Geography, 38, 1, 131-40

Ware, A. (2012) The Big Society and Conservative politics: Back to the future or forward to the past? The Political Quarterly special issue on the Big Society, 82, 82-97. 
Whiteley, P. (2012) Political participation in Britain: The decline and revival of civic culture. Basingstoke: Palgrave Macmillan

Williams, A. Goodwin, M. and Cloke, P. (2014) Neoliberalism, Big Society and progressive localism. Environment and Planning A, 46, 2798-2815

Wills, J. (2012) The geography of community and political organisation in London, Political Geography, 31, 114-126.

Wills, J. (2016) Locating localism: Statecraft, citizenship and democracy. Bristol: Policy Press.

Wilson, D. (1999) Exploring the limits of public participation in local government. Parliamentary Affairs, 52, 2, 246-259

\footnotetext{
' There is of course a much longer history of community-led planning initiatives in the United Kingdom. As an example, the communities based in London's docklands launched their own 'People's Plan' to oppose the planned development of the area during the 1980s, conducting very large scale consultation around alternative agendas for change (Brownhill, 1990; Colenutt, 1991). As such, neighbourhood planning is especially significant because it grants the community the right to set their own ambitions in the print of the plan.

ii From Holbeck Neighbourhood Forum's website: http://www.holbeckneighbourhoodplan.org.uk/

iii In the early days of their efforts to establish a neighbourhood forum the group encountered great hostility from officers in Haringey Council. The Labour Cabinet were not open to the idea of neighbourhood planning and this influenced the approach of the staff. However, this improved as time went on, not least because the officers in Haringey began to work alongside more helpful people from Camden (also Labour controlled).
}

iv Although it might seem rather unusual for a local authority to initiate a new urban forum, a larger research project conducted in 2014 found that as many as a quarter of forums were initiated by the local authority (Parker et al, 2014, 18). 